Peran Unit Pemberantasan Pungutan..........(Nizar)

\title{
PERAN UNIT PEMBERANTASAN PUNGUTAN LIAR KEMENTERIAN HUKUM DAN HAK ASASI MANUSIA DALAM MEWUJUDKAN AKUNTABILITAS DAN INTEGRITAS APARATUR
}

\author{
(Roles of The Illegal Levy Eradication Unit of The Ministry of Law and Human \\ Rights in Creating Apparatuses Accountability and Integrity)
}

\author{
Nizar Apriansyah \\ Pusat Pengkajian dan Pengembangan Kebijakan \\ Badan Penelitian dan Pengembangan Hukum dan Hak Asasi Manusia \\ Kementerian Hukum dan Hak Asasi Manusia Republik Indonesia \\ Jalan HR Rasuna Said Kavling 4-5, Jakarta Selatan 12940 \\ Telepon (021) 2525015 Faksimili (021) 2526438 \\ Email: nizarapriansyah@yahoo.com
}

Tulisan Diterima: 29 Agustus 2017; Direvisi: 20 Maret 2018;

Disetujui Diterbitkan: 20 Maret 2018

DOI: http://dx.doi.org/10.30641/kebijakan.2018.V12.21-38

\begin{abstract}
Abstrak
Penelitian ini bertujuan untuk memecahkan permasalahan yang terkait dengan Peran Unit Pemberantasan Pungli Kementerian Hukum dan Hak asasi Manusia. Permasalahan yang timbul dalam penelitian ini pertama bagaiman peran Unit Pemberantasan Pungli dan apa yang menjadi penghambat dalam pelaksanan sapu bersih pungutan liar. Kedua bagaimana peran Unit Pemberantasan Pungli dapat mewujudkan akuntabilitas dan integritas aparatur dalam pelaksanaan tugas dan fungsi. Metode penelitian yang digunakan adalah mengabungkan metode penelitian normatif dan metode penilitian empiris (mixed methods). Pengumpulan data dengan melakukan penyebaran kuesioner kepada anggota tim Unit Pemberantasan Pungli, Petugas unit layanan dan masyarakat penguna layanan. Sampel lokasi didasarkan atas keterwakilan willayah Barat, Tengah dan Timur Indonesia. Hasil penelitian menunjukan bahwa peran Unit Pemberantasan Pungli sudah berjalan tetapi belum maksimal, dan masih ada beberapa kendala dalam pelaksanaannya diantaran belum tersedianya aggaran khusus untuk kegiatan Unit Pemberantasan Pungli, mekanisme kerja belum diatur dan belum ada standar operasional prosedur. Tingkat korelasi antara peran Unit Pemberantasan Pungli dalam mewujudkan akuntabilitas dan integritas aparatur dalam pelaksanaan tugas dan fungsi rata-rata menunjukan tingkat korelasi yang positif.
\end{abstract}

Kata kunci: Pemberantasanan, Pungutan, Liar, Kemenkumham

\begin{abstract}
This research is aimed to solve the problems related to the Roles of Illegal Levy Eradication Unit of the Ministry of Law and Human Rights. The subjects of this research are, firstly, the roles of the Illegal Levy Eradication Unit and the barriers that hamper the eradication of illegal levy. Secondly, the roles of Illegal Levy Eradication Unit in creating apparatuses accountability and integrity during the performance of their duties and functions. The method employed in this the research mixes normative research method and empirical research method (mixed methods). Data are collected by disseminating questionnaires to the members of Illegal Levy Eradication Unit teams, the public services officials and the people using the services. Sampling locations observe the representation of Western, Central and Eastern Indonesia areas. The research shows that the Illegal Levy Eradication Unit has operated well but not to its maximum level, and there have been some barriers in their performance among others, there have been no specifically designated budget to support the activities of the Illegal Levy Eradication Unit, no regulation on work mechanism and no standard operational procedures. Correlation index between the roles of Illegal Levy Eradication Unit in creating apparatuses accountability and integrity during the performance of their duties and functions in average has demonstrated positive correlation.
\end{abstract}

Keywords: Eradication, Illegal Levy, Ministry of Law and Human Rights 


\section{PENDAHULUAN}

\section{Latar Belakang}

Data Ombudsman RI mencatat, dari tiga perbuatan maladministrasi, tindakan penundaan berlarut-larut menempati urutan pertama. Pada tahun 2015 tercatat sebanyak 1.319 laporan tindakan berlarutlarut, sedangkan pada 2016 meningkat menjadi 2.246 laporan atau meningkat $70,3 \%$. Sedangkan pada perbuatan maladministrasi tidak memberi pelayanan, tahun 2015 tercatat sebanyak 874 laporan dan meningkat pada 2016 menjadi 1.052 laporan atau 15,2 \% Untuk tindakan maladministrasi pungutan liar (pungli) dan suap, pada 2015 tercatat sebanyak 384 laporan yang masuk ke Ombudsman, dan pada 2016 meningkat menjadi 434 laporan atau $13 \%{ }^{1}$

Pungutan liar (Pungli) termasuk dalam kategori kejahatan jabatan, Dalam rumusan korupsi pada Pasal 12 huruf e Undangundang Nomor. 20 Tahun 2001 berasal dari Pasal 423 KUHP yang dirujuk dalam Pasal 12 UU Nomor.31 Tahun 1999 sebagai tindak pidana korupsi, yang kemudian dirumuskan ulang pada Undang-undang Nomor 20 Tahun 2001 (Tindak Pidana Korupsi), menjelaskan definisi pungutan liar adalah suatu perbuatan yang dilakukan pegawai negeri atau penyelenggara yang dengan maksud menguntungkan diri sendiri atau orang lain secara melawan hukum, atau dengan menyalahgunakan kekuasaannya memaksa seseorang memberikan sesuatu, membayar, atau menerima pembayaran dengan potongan, atau untuk mengerjakan sesuatu bagi dirinya sendiri.

Istilah lain yang dipergunakan oleh masyarakat mengenai pungutan liar atau pungli adalah "uang sogokan, uang pelican, salam tempel" dan lain-lain. Pungli pada hakekatnya adalah interaksi antara petugas dengan masyarakat yang didorong oleh berbagai kepentingan pribadi. $^{2}$ Terdapat

1 Data Ambusmen RI Tahun 2015-2016 sumber http://www.hukumonline.com/berita/baca/lt581c9e 3ec32fa/waspadai-modus-pungli-dan-potensikorupsi diakses 15/8/2017

${ }^{2}$ Soedjono, Dirdjosisworo.. Pungli: Analisa Hukum \& Kriminologi, cetakan ke-2. Bandung: Sinar Baru. 1983. hal 15 beberapa faktor yang menyebabkan seseorang melakukan pungli, yaitu:

1. Penyalahgunaan wewenang. Jabatan atau kewenangan seseorang dapat melakukan pelanggaran disiplin oleh oknum yang melakukan pungutan liar.

2. Faktor mental. Karakter atau kelakuan dari pada seseorang dalam bertindak dan mengontrol dirinya sendiri.

3. Faktor ekonomi. Penghasilan yang bisa dikatakan tidak mencukupi kebutuhan hidup tidak sebanding dengan tugas/jabatan yang diemban membuat seseorang terdorong untuk melakukan pungli.

4. Faktor kultural \& budaya organisasi. Budaya yang terbentuk di suatu lembaga yang berjalan terus menerus menyebabkan pungli dan penyuapan menjadi hal biasa.

5. Terbatasnya sumber daya manusia.

6. Lemahnya sistem kontrol dan pengawasan oleh atasan/atasan membiarkan karena menjadi salah satu mata rantainya. ${ }^{3}$

Untuk mengatasi permasalahan pungli tersebut dengan menimbang bahwa praktik pungutan liar telah merusak sendi kehidupan bermasyarakat, berbangsa, dan bernegara sehingga perlu upaya pemberantasan secara tegas, terpadu, efektif, efisien, dan mampu menimbulkan efek jera. Presiden Republik Indonesia Bapak Joko Widodo mengeluarkan Peraturan Presiden Republik Indonesia Nomor 87 Tahun 2016 Tentang Satuan Tugas Sapu Bersih Pungutan Liar. Dengan Peraturan Presiden ini dibentuk Satuan Tugas Sapu Bersih Pungutan Liar yang selanjutnya disebut Satgas Saber Pungli. Satgas Saber Pungli sebagaimana dimaksud pada Ayat (1) berkedudukan di bawah dan bertanggung jawab kepada Presiden. Pasal 2 Satgas Saber Pungli mempunyai tugas melaksanakan pemberantasan pungutan liar secara efektif dan efisien dengan mengoptimalkan pemanfaatan personil, satuan kerja, dan sarana prasarana, baik yang berada di kementerian/lembaga maupun pemerintah daerah. Kementerian/lembaga dan pemerintah daerah melaksanakan 
pemberantasan pungutan liar di lingkungan kerja masing-masing. Dalam melaksanakan pemberantasan pungutan liar, kementerian/lembaga dan pemerintah daerah membentuk unit pemberantasan pungutan liar. Unit pemberantasan pungutan liar berada pada satuan pengawas internal atau unit kerja lain di lingkungan kerja masingmasing. Unit pemberantasan pungutan liar yang berada pada masing-masing kementerian/lembaga dan pemerintah daerah, dalam melaksanakan tugasnya berkoordinasi dengan Satgas Saber Pungli.

Hingga saat ini Tim Satgas UPP Nasional sejak terbentuk sembilan bulan lalu telah menerima 31.110 laporan masyarakat. Rinciannya, 20.020 melalui pesan singkat (SMS), via e-mail sebanyak 6.641 laporan, via website ada 1.960 laporan, melalui call centre 193 ada 1.877 laporan, surat 518 laporan dan terakhir melalui pengaduan langsung sebanyak 94. Pengaduan terbanyak berasal dari sektor pelayanan masyarakat yang mencapai 36 persen. Selanjutnya laporan pungli di bidang hukum (26\%), pendidikan $(18 \%)$, perizinan $(12 \%)$ dan kepegawaian (8\%). Satgas dan UPP saber pungli telah berhasil melakukan operasi tangkap tangan (OTT) sebanyak 917 kegiatan dengan jumlah tersangka mencapai 1.834 orang dari berbagai instansi dan lembaga. Sedangkan barang bukti uang yang disita mencapai Rp 17.623.205.500. ${ }^{4}$

Kementerian Hukum dan Hak Asasi Manusia (Kemenkumham) ${ }^{5}$ untuk menindaklanjuti peraturan presiden tersebut melalui Menteri Hukum dan Hak Asasi Manusia pada tanggal 13 Oktober 2016 mengeluarkan keputusan Nomor M.HH04.PW.02.03 Tahun 2016 Tentang Tim Pementau Pemberantasan Pungutan Liar di Lingkungan Kementerian Hukum dan HAM. Kemudian dalam pelaksanaan pemberantasan Pungli di Lingkungan Kemenkumham, Menteri Hukum dan Hak

\footnotetext{
${ }^{4}$ Berdasar data yang disampaikan

Sesmenkopolhkam Letjen Yoedhi Swastono pada Workshop Nasional Saber Pungli yang diikuti oleh semua tim UPP kementerian dan lembaga (K/L) Rabu (2/8) di Hotel Mercure Convention Ancol, http://m.radarbangka.co.id/berita/detail/nusantara/4 5838/tim-saber-pungli-kemenkumham-fokussentuh-lapas-dan-imigrasi.html

${ }^{5}$ Kementerian Hukum dan Hak Asasi Manusia, selanjutnya dalam kajian ini di sebut dengan Kemenkumham.
}

Asasi Manusia pada tanggal 2 November 2016 mengeluarkan keputusan Nomor M.HH-06.PW.02.03 Tahun 2016 Tentang Unit Pemberantasan Pungutan Liar di Lingkungan Kementerian Hukum dan Hak Asasi Manusia. Dalam melaksanakan tugas Unit Pemberantasan Pungutan liar di lingkungan Kemenkumham menyelenggarakan fungsi: Pencegahan, Penindakan dan Yustisi. Dalam melaksanakan tugas UPP Kemenkumham mempunyai wewenang sebagai berikut ${ }^{6}$ :

a. Membangun sistem pencegahan dan pemberantasan pungli

b. Melakukan pengumpulan data dan informasi dari kementerian/lembaga dan pihak lainnya yang terkait dengan pengunaan teknologi informasi;

c. Mengkoordinasikan, merencanakan, dan melaksanakan operasi pemberantasan pungli;

d. Melaksanakan operasi tangkap tangan;

e. Memberikan rekomendasi kepada Menteri Hukum dan HAM serta Kepala Kantor Wilayah Kementerian Hukum dan HAM, untuk memberikan sanksi kepada pelaku pungli sesuai ketentuan peraturan perundangan -undangan

f. Memberikan rekomendasi pembentukan dan pelaksanaan tugas unit pemberantasan pungutan liar sesuai dengan ketentuan peraturan perundang-undangan

g. Melaksanakan evaluasi kegiatan pemberantasan pungli

Pemberantasan pungli merupakan salah satu upaya strategis bagi Kemenkumham dalam rangka meningkatkan percepatan, keakuratan penanganan, dan penyelesaian pungli. Hal ini diharapkan dapat meningkatkan kepercayaan masyarakat (public trust) terhadap Kemenkumham, walau dirasakan sulit untuk sama sekali memberatas pungli yang ada di lingkungan Kemenkumham, karena Kemenkumham salah satu kementerian yang memiliki Kantor Wilayah (Kanwil) di sertiap lbu kota Provinsi dan memiliki Unit Pelaksanan Teknis (UPT) di tingkat kabupaten/kota tentunya akan menjadi kendala tersendiri dalam pengawasan dan penanganan pungli. Sampai saat ini Kemenkumham memiliki 1.081 satuan kerja terdiri dari 11

\footnotetext{
${ }^{6}$ Keputusan Nomor M.HH-06.PW.02.03 Tahun 2016 Tentang Unit Pemberantasan Pungutan Liar di Lingkungan Kementerian Hukum dan Hak Asasi Manusia.Butir ke Empat
} 
Unit Esslon 1, 34 Kantor Wilayah (Kanwil), 269 Lembaga Pemasyarakatan (lapas), 162 Rumah Tahanan Negara (Rutan), 59 Cabang Rutan (Cabrut), 33 Lembaga Pembinaan Khusus Anak (LPKA), 4 Lembaga Penempatan Anak Sementara (LPAS), 63 Rumah Penyimpanan Benda Sitaan Negara (Rupbasan), 71 Balai Pemasyarakatan (Bapas), 5 Kantor Kurator Negara dan Balai Harta Peninggalan, 1 Rumah Sakit Pengayoman, 125 Kantor Imigrasi, 13 Rumah Detensi Imigrasi (Rudenim), 19 Perwakilan RI di Luar Negeri, 79 Pos Lintas Batas , 130 Tempat Pemeriksaan Imigrasi (TPI), 1 Pusdatin, 1 Poltekip, dan 1 Poltekim, dengan 3.741 Pegawai Pusat dan 43.529 Pegawai Kanwil dan UPT

Dari 1.081 satuan kerja di Kemenkumham, Unit Pemasyarakatan dan unit layanan Keimigrasian yang sering menjadi pemberitaan hangat media televisi maupun media cetak, menurut data dari UPP Kemenkumham, layanan administrasi dan layanan fasilitatif maupun layanan publik patut diduga dapat juga terjadi pungli, walaupun sebagian layanan yang ada di lingkungan Kemenkumham sebagian sudah melalui sistem online. Berikut adalah peta titik rawan pungli yang sudah dipetakan oleh UPP Kemenkumham sebagai berikut :

Tabel 1.Pelaksanaan Tugas dan Fungsi Administratif Rawan terjadi Pungli Di Lingkungan Kemenkumham ${ }^{7}$

\section{BIDANG ADMINISTRATIF DAN}

\section{FASILITATIF}

\section{Peneriman CPNS}

Pengadaan Barang dan Jasa

Kenaikan Pangkat

Kenaikan Jabatan Promosi dan Mutasi

Diklat

Pelaksanan Tugas Pengawasan oleh APIP (Audit, Evaluasi, Reviu, Pendamping dan pengawas lainnya)
Penyalagunaan wewenang yang berujung pungli di lingkungan Inspektorat Jenderal di luar tugas pengawasan.

Pengharmonisasian Peraturan

Perundang-Undangan

Pengundangan Peraturan

Kementerian/Lembaga

Pembinaan Kepegawaian

Pembinaan Perancang

Pemberian Bantuan Hukum oleh Pemberi Bantuan Hukum (OBH) kepada penerima Bantuan Hukum (orang miskin)

(Data Berdasarkan: Peta Titik Rawan Pungli UPP Kemenkumham Tahun 2017)

Tabel 2.Pelaksanaan Tugas dan Fungsi Layanan Rawan terjadi Lingkungan Kemenkumham ${ }^{8}$

Pungli Di

\section{BIDANG PELAYANAN PUBLIK}

Layanan Pembebasan bersyarat bagi warga Binaan Pemasyarakatan

Layanan Pemberian remisi bagi Warga Binaan Pemasyarakatan

\section{Layanan Cuti Bersyarat bagi Warga}

Binaan pemasyarakatan

Layanan Cuti Mengunjungi keluarga

Layanan Kunjungan bagi warga Binaan

Loket layanan Kekayaan Intelektual

Peroses permohonan, pemeriksaan, sertifikasi: Merek, Paten dan Hak Cipta

Pelayanan Badan Hukum

Pelayanan Kenoktariatan

Pelayanan Kewarganegaraan

Pelayanan Pewarganegaraan

\footnotetext{
${ }^{8}$ Pemetaan Titik Rawan Pungli UPP

Kemenkumham: 2017
}

\footnotetext{
${ }^{7}$ Pemetaan Titik Rawan Pungli UPP

Kemenkumham: 2017
} 


\section{Pelayanan Harta Peninggalan Wasiat dan Pailit}

Pelayanan Jaminan Fidusia

\section{Pelayanan Badan Hukum Partai Politik}

Pelayanan Legislasi

\section{Pelayanan Penerjemah Bersumpah}

Pelayanan penyidik Pegawai Negeri Sipil

\section{Pembayaran Penerimaan Negara Bukan \\ Pajak (PNBP) untuk layanan Jasa Hukum}

\section{Pelayanan pada loket pelayanan terpadu Ditjen AHU}

\section{Pengurusan dan Perpanjangan Paspor ${ }^{9}$}

(Data Berdasarkan: Peta Titik Rawan Pungli UPP Kemenkumham Tahun 2017)

Dalam pelaksanaannya UPP, terdiri dari UUP Pusat dan Satgas Saber Pungli Kanwil dan UPT. Satgas Saber Pungli Kanwil adalah perpanjangan dari UPP Pusat yang telah dibentuk di Kemenkumham, yang berfungsi untuk melakukan pengawasan dan inspeksi mendadak terhadap seluruh pelayanan yang ada di lingkungan Kemenkumham, kemudian melaporkan hasil pengawasan dan sidak tersebut ke Menteri Hukum dan HAM. Tim UPP beranggotaka sebanyak 33 orang, dan Kakanwil selaku penanggung jawab di tingkat wilayah yang terdiri dari tiga Pokja, yaitu Pokja unit pencegahan, Pokja unit Penindakan, dan Pokja unit Yustisi. Dalam pelaksanaanya UPP dipantau oleh tim Pemantau Pungli yang terdiri dari para pejabat Esslon 1 di lingkungan Kemenkumham.

Pemberantasan pungli sebenarnya bukan suatu hal baru melalui Reformasi Birokrasi yang terus melakukan berbagai upaya membangun tata kelola pemerintahan yang baik dan bersih (good governance and clean government). Salah satu upaya itu dilakukan dengan membangun zona integritas ( $\mathrm{ZI}$ ) menuju

\footnotetext{
${ }^{9}$ Fuska Sani Evani/PCN:

http://www.beritasatu.com/hukum/398101-petugasimigrasi-yogya-terkena-ott-satgas-pungli.html diakses 27 Maret 2017.
}

wilayah bebas dari korupsi (WBK) dan wilayah birokrasi bersih melayani (WBBM). hal ini tentu saja bertujuan untuk membangaun unit layanan yang baik serta Aparatur Sipil yang akuntabel dan berintegritas tinggi. Secanggih apapun sistem pemerintahan, namun jika Sumber Daya Manusia (SDM) tidak memiliki integritas, maka praktek pungli akan tetap ada. Dibentuknya UPP dan Satgas Saber Pungli di Kemenkumham bertujuan untuk menjaga kesadaran pegawai dengan terus menjaga nilai-nilai integritas dan akuntabilitas.

Salah satu faktor yang berpengaruh terhadap terjadinya pungli adalah Akuntabilitas dan Integritas aparatur. Nilai akubilitas atau accountable merupakan konsep yang berkenaan dengan standar eksternal yang menentukan kebenaran suatu tindakan oleh birokrasi publik. Karenanya akuntabilitas ini disebut tanggung jawab yang bersifat objektif, sebab birokrasi dikatakan accountable bilamana dinilai baik oleh penguna layanan/ masyarakat dan dapat mempertanggungjawabkan segala macam perbuatan, kepada pihak kekuasaan dimana kewenangan yang dimiliki itu berasal ${ }^{10}$. Sedangkan nilai Integritas adalah kunci utama untuk memberantas pungli. Karakter integritas pada dasarnya meliputi kejujuran, kemandirian, dan kedisiplinan. Karakterkarakter inilah yang harus dimiliki agar seseorang dapat bebas dari pungli dan korupsi. Tanpa adanya integritas dalam diri seseorang, hampir mustahil pungli dapat diberantas. Sesempurna apapun sebuah sistem akan menjadi sistem yang korup apabila dijalankan oleh orang-orang yang tidak berintegritas. Oleh karena itu, aspek integritas dalam organisasi sektor publik harus menjadi perhatian utama sehingga dapat menghasilkan organisasi publik yang bebas dari praktek korups ${ }^{11}$

\footnotetext{
${ }^{10}$ I wayan sudana: Mewujudkan Birokrasi yang Mengedepankan Etika Pelayanan Publik: 2006

https://ilmupemerintahan.wordpress.com/2009/06/ 06/mewujudkan-birokrasi-yang-mengedepankanetika-pelayanan-publik/

${ }^{11}$ Ardeno Kurniawan, S.E., M.Acc, Ak.: Fraud di Sektor Publik dan Integritas Nasional : http://www.bpkp.go.id/public/upload/unit/sulsel/files /paraikatte/26_paraikatte_edisi_26_1_web.pdf diakses 1 Maret 2017
} 
Melalui penelitian ini maka penting untuk mengetahui apakah peran UPP mampu untuk mendorong integritas dan akuntabilitas dalam pelaksanaan tugas dan fungsi pegawai di lingkungan Kemenkumham.

\section{Rumusan Masalah}

Berdasarkan latar belakang masalah di atas maka yang menjadi pertanyaan mendasar dalam kajian ini adalah ;

1. Bagaimana peran UPP dalam melaksanakan program pemerintah untuk melaksanakan sapu bersih pungutan liar di lingkungan Kemenkumham?

2. Apa saja yang menjadi penghambat yang dialami UPP dalam pelaksanaan pemberantasan pungli di lingkungan Kemenkumham?

3. Apakah peran UPP dapat mewujudkan akuntabilitas dan integritas aparatur dalam pelaksanaan tugas dan fungsi ?

\section{Tujuan}

Penelitian ini bertujuan

1. Mengetahui dan memecahkan permasalahan Peran UPP di lingkungan Kemenkumham

2. Untuk mengetahui penghambat yang dialami UPP dalam pelaksanaan pemberantasan pungli di lingkungan Kemenkumham

3. Untuk mengetahui dan menganalisis peran UPP mewujudkan akuntabilitas dan integritas aparatur dalam pelaksanaan tugas dan fungsi

\section{Metodologi Penelitian}

\section{Pendekatan}

Metode Penelitian yang digunakan adalah menggabungkan Metode Penelitian Normatif dan Metode Pemelitian Empiris, Pendekatan kuantitatif digunakan untuk menangani data-data (angka) yang berguna untuk mengukur tingkat kecenderungan dari jawaban responden yang terkait dengan pokok permasalahan. Sedangkan pendekatan kualitatif berguna untuk memaksimalkan semua informasi yang terkait dengan pokok permasalahan guna mendapatkan data yang lebih mendalam dan komprehensif.

\section{Metode Pengumpulan data}

Metode pengumpulan data dengan mengunakan kuesioner berisi daftar pertanyaan secara tertulis yang ditujukan kepada subjek/responden baik yang tertutup (berstruktur) maupun yang terbuka (tidak berstruktur). responden yang kami pilih terdiri atas responden Unit Kanwil dan UPT. Unit Kanwil dan UPT tersebut dibagi berdasarkan tugas sebagai Satgas Saber pungli dan Petugas Unit Layanan. Pertanyaan-pertanyaan yang muncul pada questioner dibagi berdasarkan jenis pekerjaan antara Satgas Saber Pungli dan petugas layanan di UPT dan Kanwil.

\section{Teknik Penarikan Sampel}

Data yang akan dikumpulkan terdiri dari data primer (field research) yang didapat dari data empiris berupa data kualitatif dan data kuantitatif yang dikumpulkan dari setiap subjek data. Lokasi yang dipilih berdasarkan keterwakilan wilayah Barat, Tengah dan Timur Indonesia ditetapkan secara purposive sampling terdiri dari DKI. Jakarta, Jawa Barat, Sumatera Utara, Bali, dan Nusa Tengara Barat. Sebagai sampel kajian dipilih Kantor Wilayah Kemenkumham, Kantor Imigrasi dan Lembaga Pemasyarakatan. Populasi kajian terdiri dari 34 Kanwil Kemenkumham. Responden 190 orang yang terdiri dari: 79 Orang dari Penguna Unit layanan yang terdiri dari pemohon paspor di kantor Imigrasi, Warga Binaan Pemasyarakatan dan Pengunjung Warga Binaan Pemasyarakatan di Lembaga Pemasyarakatan. 54 Orang Petugas Unit layanan Imigrasi dan Lembaga Pemasyarakatan, 57 Orang Tim UPP Kanwil dan Satgas Saber Pungli UPT.

\section{Metode Analisa Data}

Data yang terkumpul sebelumnya dilakukan pengkodingan terlebih dahulu kemudian dipilah menjadi dua jenis data, yaitu data kuantitatif dan data kualitatif. Data kuantitatif didapat dari pertanyaan tertutup terstruktur, data ini didapat dari pentabulasian melalui sistem tally, berguna untuk mengukur tingkat kecenderungan dari jawaban-jawaban responden. Kemudian data kualitatif didapat dari pertanyan terbuka hal ini berguna untuk melihat alasan responden dan kendala-kendala pelaksanaan pemberantasan pungli di lingkungan Kemenkumham. 
Untuk mengukur hubungan UPP untuk meningkatkan akuntabilitas dan Integritas dengan mengunakan skala likert. Skala likert digunakan untuk mengukur sikap, pendapat dan persepsi pegawai terhadap peran UPP/Satgas saber pungli di lingkungan Kemenkumham dengan skala likert. Variabel yang akan diukur variabel (X) peran UPP dengan variabel (Y) Akuntabilitas dan Integritas pada kajian ini dengan mengunakan teknik pearson product moment correlation. Untuk menghitung tingkat hubungan korelasi mengunakan IMB SPSS Statistics verson 24 dengan analyze - correlate - bivariate.

Tabel 3. Rentang Skala Likert

\begin{tabular}{lccccc}
\hline $\begin{array}{l}\text { Peryat } \\
\text { aan } \\
\text { Sikap }\end{array}$ & $\begin{array}{c}\text { Sang } \\
\text { at } \\
\text { Setuj } \\
\text { u }\end{array}$ & $\begin{array}{c}\text { Setuj } \\
\text { u }\end{array}$ & $\begin{array}{c}\text { Ra } \\
\text { gu- } \\
\text { rag } \\
\text { u }\end{array}$ & $\begin{array}{c}\text { Tida } \\
\text { Setuj } \\
\text { u }\end{array}$ & $\begin{array}{c}\text { Sangat } \\
\text { Tidak } \\
\text { Setuju }\end{array}$ \\
\hline Positif & $\mathbf{5}$ & $\mathbf{4}$ & $\mathbf{3}$ & $\mathbf{2}$ & $\mathbf{1}$ \\
Negatif & $\mathbf{1}$ & $\mathbf{2}$ & $\mathbf{3}$ & $\mathbf{4}$ & $\mathbf{5}$
\end{tabular}

Sumber : Saodih : $2007: 240$

Tabel 4.Pedoman untuk memberikan Interprestasi Koefisien Korelasi

\begin{tabular}{|c|c|}
\hline $\begin{array}{c}\text { Interval } \\
\text { Koefisien }\end{array}$ & Tingkat Hubungan \\
\hline $0,00-0,199$ & Sangat Rendah \\
\hline $0,20-0,399$ & Rendah \\
\hline $0,40-0,599$ & Sedang \\
\hline $0,60-0,799$ & Kuat \\
\hline $0,80-1,000$ & Sangat Kuat \\
\hline
\end{tabular}

Sumber : Sugiono : $2008: 257$

Untuk melakukan interpretasi kekuatan hubungan kedua variabel tersebut, dilakukan dengan melihat angka koefesien korelasi hasil perhitungan dengan menggunakan kriteria sebagai berikut :

- Jika angka koefesien korelasi menunjukkan 0 , maka kedua variabel tidak mempunyai hubungan

- Jika angka koefesien korelasi mendekati 1, maka kedua variabel mempunyai hubungan semakin kuat

- Jika angka koefesien korelasi mendekati 0 , maka kedua variabel mempunyai hubungan semakin lemah
- Jika angka koefesien korelasi sama dengan 1, maka kedua variabel mempunyai hubungan linier sempurna positif.

- Jika angka koefesien korelasi sama dengan -1 , maka kedua variabel mempunyai hubungan linier sempurna negatif.

Adapun hipotesa yang akan di ukur hipotesa :

H1 : Ada hubungan Peran UPP Kemenkumham dengan peningkatan Akuntabilitas dan Integritas pegawai dalam pelaksanaan tugas dan fungsi.

HO : Tidak ada Peran UPP Kemenkumham dengan peningkatan Akuntabilitas dan Integritas pegawai dalam pelaksanaan tugas dan fungsi.

\section{PEMBAHASAN}

\section{A. Peran Unit Pemberantasan Pungli dalam Pelaksanaan Program sapu bersih pungutan liar (saber pungli) di Kementerian Hukum dan HAM}

\section{Pembentukan tim Saber Pungli}

Sebagai bentuk keseriusan

Kemenkumham terhadap pemberantasan Pungli, para anggota Tim Unit Pemberantasan Pungutan Liar (UPP) Pungli Kemenkumham mengucapakan ikrar atau janji yang dibacakan langsung oleh Irjen Kemenkumham yang sekaligus juga sebagai ketua pemantau ${ }^{12}$ dan Ketua Pelaksana Pemberantasan Pungli di Lingkungan Kemenkumham. Pengukuhan UPP di Kemenkumham, dilakukan di saat apel pagi Senin $(07 / 11)^{13}$ oleh Menteri Hukum dan Hak Asasi Manusia Yasonna $\mathrm{H}$ Laoly, Inspektur Jenderal Kemenkumham Aidir Amin Daud dikukuhkan sebagai Ketua Tim pelaksana beserta beberapa orang pejabat lainnya yang masuk dalam Tim UPP. Pengukuhan tersebut dikuatkan oleh Surat Keputusan Menteri Hukum dan HAM Nomor: M.HH-06.PW.02.03 Tahun 2016 tanggal 02 November 2016 tentang Unit Pemberantasan Pungutan Liar di Lingkungan Kementerian Hukum dan HAM. Di bentuknya Tim UPP di Lingkungan Kemenkumham adalah sebagai tindak lanjut dari Peraturan Presiden (Perpres) No 87 tahun 2016 tentang

\footnotetext{
${ }^{12}$ Republik Indonesia, Keputusan Menteri Hukum dan HAM RI, Nomor M.HH-04.PW.02.03 Tahun 2016 tentang Tim Pemantau Pemberantasan Pungutan Liar di Lingkungan Kementerian Hukum dan HAM.

${ }^{13} \mathrm{http} / / /$ itjen.kemenkumham.go.id/berita-utama/815upp-pungli-kemenkumham diakses $13 / 8 / 17$
} 
satgas Saber Pungli yang telah menjadi dasar bagi tiap Kementerian/Lembaga serta Pemerintah Daerah dalam menangulangi pungli di lingkungan kerja masing-masing.

\section{Pelaksanaan Saber Pungli di Kemenkumham}

Upaya pemberantasan Pungli di lingkungkan Kemenkumham ditandai dengan terbentuknya Tim UPP sebagai tindak lanjut dari Peraturan Presiden Republik Indonesia Nomor 87 Tahun 2016 Tentang Satuan Tugas Sapu Bersih Pungutan Liar, Pasal 8 Ayat 1 menyatakan bahwa :

Pasal (1) Kementerian/lembaga dan pemerintah daerah melaksanakan pemberantasan pungutan liar di lingkungan kerja masing-masing.

Pasal (5) Unit pemberantasan pungutan liar yang berada pada masing-masing kementerian/lembaga dan pemerintah daerah sebagaimana dimaksud pada ayat (3), dalam melaksanakan tugasnya berkoordinasi dengan Satgas Saber Pungli.

Dalam upaya pelaksanaan pemberantasan pungli di lingkungan Kemenkumham diwajibkan setiap Kantor Wilayah dan Unit Pelaksana Teknis untuk membentuk Tim saber pungli. Adapun pelaksanaan Tim UPP, dilihat dari komposisi keanggotaan yang dibentuk oleh kantor wilayah dan UPT. Berdasarkan tangapan 57 dari UPP Kanwil dan UPT responden Unit Kanwil dan UPT menunjukan bahwa:

\section{Gambar 1. Komposisi Keangotaan Tim UPP di Kanwil Kemenkumham}

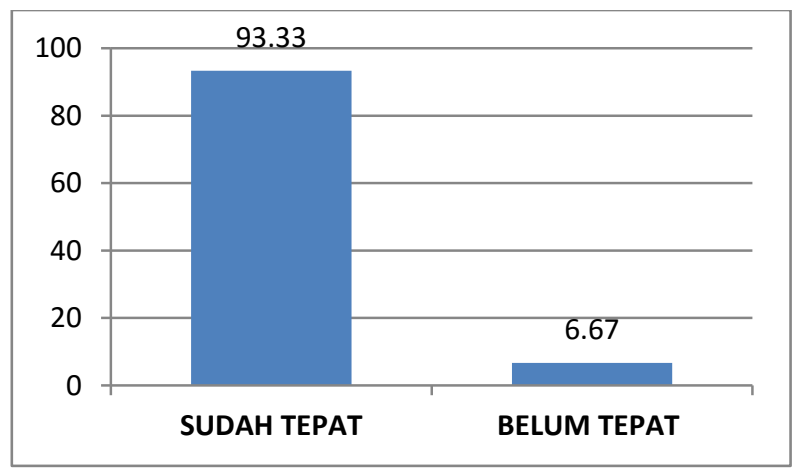

Data di atas terlihat bahwa responden beranggapan bahwa komposisi dari keanggotan tim UPP yang berada di kanwil dan UPT menunjukan sudah tepat (93\%) karena, sebagian besar responden beranggapan bahwa dalam perekrutan keanggotaan tim UPP sudah mengikutsertakan semua unsur pada semua Divisi, dengan memperhatikan keahlian setiap individu. Sedangkan responden yang beranggapan belum tepat $(7 \%)$ memandang bahwa dalam komposisi keanggotaan tim UPP perlu melibatkan anggota dari pihak luar, hal ini bertujuan untuk melihat objektifitas pelaksanaan program sapu bersih pungli di Kemenkumham. Menurut responden, jika yang terlibat semua dari unsur Kemenkumham tentu saja objektifitasnya dipertanyaakan. Dalam pelaksanaanya Tim UPP, perlu diperhatikan juga adanya kesediaan posko khusus tim UPP hal ini akan berguna untuk mempermudah pelaporan dalam menunjang kerja tim, serta ada pembagian tugas yang jelas setiap pokja yang ada. Jika dilihat dari sisi organisasi adalah perkumpulan atau wadah bagi sekelompok orang untuk bekerjasama, terkendali dan terpimpin untuk tujuan tertentu ${ }^{14}$, dimana dalam melakukan tindakan itu ada pembagian tugas, wewenang dan tanggung jawab bagi tiap-tiap personal yang terlibat di dalamnya untuk mencapai tujuan organisasi. Menilai apakah organisasi itu efektif atau tidak, ada banyak pendapat antara lain mengatakan bahwa suatu organisasi efektif atau tidak, secara keseluruhan ditentukan oleh apakah tujuan organisasi itu tercapai dengan baik atau sebaliknya. Teori yang paling sederhana ialah teori yang berpendapat bahwa efektivitas organisasi sama dengan prestasi organisasi secara keseluruhan, pandangan yang juga penting adalah teori yang menghubungkan tingkat kepuasan para anggotanya. ${ }^{15}$ berdasarkan uraian tersebut diatas, jelas efektifitas organisasi UPP Kemenkumham dalam pelaksanaanya pemberantasan pungli di lingkungan Kemenkumham dapat dilihat dari capaian UPP itu sendiri.

Dalam pelaksanan peran UPP untuk memberantas pungli di lingkungan Kemenkumham, dapat diuraikan dari fungsi

\footnotetext{
${ }^{14}$ Alijah blog ;

https://aliajah.wordpress.com/2013/03/19/pengerti an-organisasi-secara-umum-dan-pengertianorganisasi-menurut-para-ahli/ berdasarkan sumber: http://tkampus.blogspot.com/2012/03/defi nisi-organisasi.html

15 Adam I. Indrawijaya. (2000). Perilaku organiasi. Jakarta Sinar baru Algesindo. hal 227
} 
- fungsi yang telah dilaksanakan oleh setiap pokja di antaranya adalah sebagai berikut.

\section{Pelaksanaan Fungsi Pencegahan}

Pelaksanaan Program kegiatan pencegahan di lingkungan Kanwil dan UPT. sebagian besar tim UPP Kanwil dan Satgas Saber Pungli UPT melakukan sosialisasi di Kanwil dan UPT. Dalam pelaksanaan sosialiasi tersebut, intensitas sosialiasi terbesar kepada pegawai dan petugas unit layanan tetapi ada juga Kanwil yang melakukan sosialiasi pungli tersebut kepada para istri PNS. Tujuannya agar para istri PNS tersebut mengetahui akibat yang akan ditimbulkan jika suami mereka melakukan tidakan pungli. Sosialiasi juga dilakukan kepada Warga Binaan Pemasyarakatan (WBP) dengan tujuan agar WBP mengetahui batasan-batasan apa saja yang diperbolehkan dan tidak diperbolehkan

\section{Pelaksanaan Fungsi Penindakan}

Dengan melakukan verifikasi laporan, pemeriksaan terhadap terlapor dan dibuat Berita Acara Pemeriksan (BAP). Kepada pegawai dan petugas unit layanan yang terindikasi melakukan pungli, tetap dilakukan tindakan hukum sesuai dengan tingkat kesalahan. Pembinaan kepada pegawai tetap terus dilakukan melalui atasan langsung dan operasi secara berkala ke sentra-sentra pelayanan yang terindikasi terdapat pungli. Laporan dari masyarakat baik secara langsung kepada kepala satuan kerja (Satker), melalui WhatsApp (WA), menghubungi melalui telepon atau melalui Situs "lapor". Sejauh ini tetap dilakukan verifikasi terhadap kebenaran dari laporan tersebut, sebelum dilakukan tindakan lebih lanjut. Dalam pelaksanaan peran penindakan, UPP Kanwil lebih banyak berkoordinasi dengan Tim UPP Kemenkumham yang berada di Jakarta, terutama dalam melakukan sidak ke UPT-UPT tertentu yang terindikasi terdapat pungli. Biasanya dilakukan bila sudah banyaknya berita yang beredar di televisi, koran, majalah maupun melalui media sosial (facebook, WA, instagram, twiters dII) yang menginformasikan suatu tindakan yang kurang baik tentang Kementerian ini.

\section{Pelaksanaan Fungsi Yustisi}

Pelaksanaan fungsi Yustisi, pendapat 64\% responden menyatakan bahwa, UPP
Kanwil harus terus berkoordinasi dengan pihak terkait lainnya dalam menentukan langkah - langkah hukum. Kemudian 36\% responden menyatakaan bahwa tim UPP dalam melakukan tindakan yustisi jika menyangkut kedisiplinan pegawai, tidak perlu berkoordinasi secara vetikal (UPP Kemenkumham Pusat) dan horizontal (pihak kepolisian dan tim saber Nasional) karena sudah ada aturan tersendiri tentang jenis dan hukuman kepada pegawai.

Peran UPP secara keseluruhan dalam menangulangi praktek pungli di Kemenkumham dapat dilihat dari tanggapakan 59 orang responden yang menjawab terhadap hal tersebut.

\section{Gambar 2. Efektifitas UUP dalam Menangulangi Pungli}

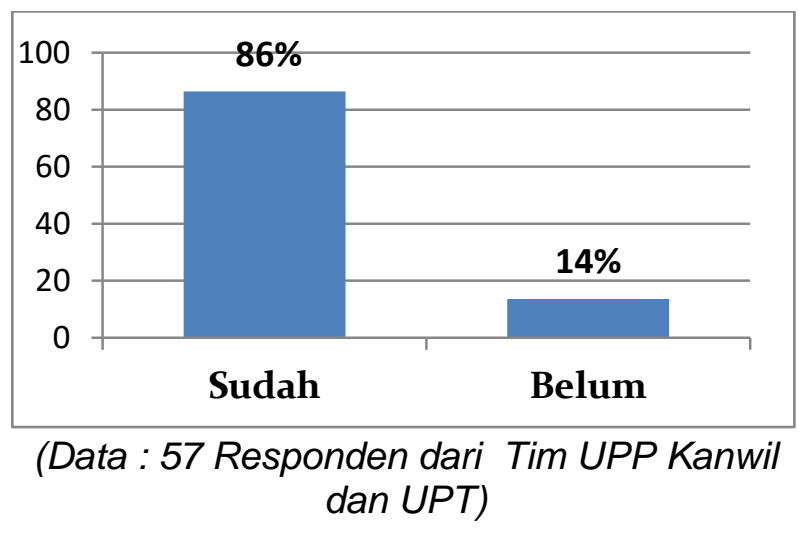

Data $86 \%$ responden menjawab UPP telah efektif menanggulagi pungli beralasan bahwa sampai saat ini sudah ada perubahan pelayanan yang lebih baik dan profesional dengan telah banyaknya layanan secara elektronik di Kementerian. Walaupun tim menilai hal ini bukan efek langsung dari pelaksanaan peran UPP Kemenkumham tetapi yang jelas keberadaan UPP patut diduga telah menstimulus perilaku pegawai. saat ini sudah timbulnya kepekaan terhadap pentingnya pelayanan yang baik, transparan dan profesional di kalangan pegawai dan petugas unit layanan. Sementara penilaian $14 \%$ Responden, menilai belum efektif karena masih kurangnya kesejahteran pegawai terutama pada unit-unit layanan di UPT. 


\section{Gambar 3. Takut melakukan pungli setelah} ada UPP di Kemenkumham

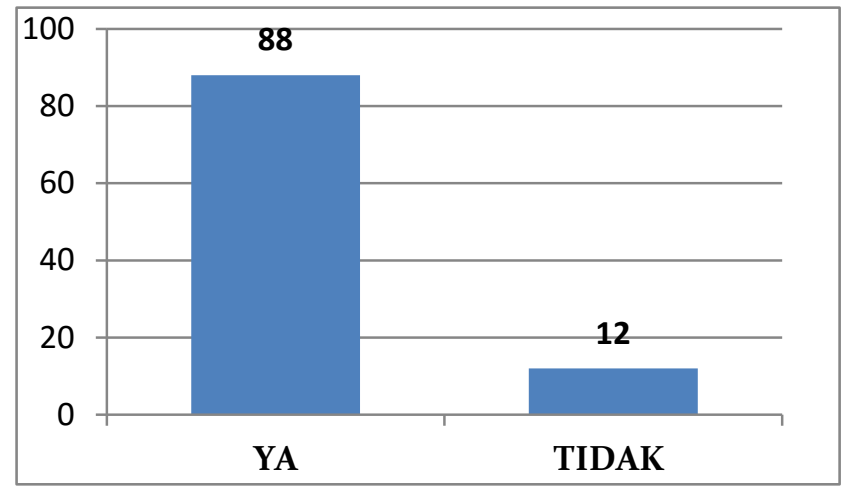

(Data : 57 Responden dari Tim UPP Kanwil dan UPT)

Alasan dari $88 \%$ responden petugas unit layanan merasa takut untuk melakukan perbuatan pungli karena takut kena operasi tangkap tangan (OTT), sekarang ini sudah banyak masyarakat yang mengetahui teknologi jadi mereka bisa melapor atau menyebarkan perbuatan pungli tersebut melalui media sosial, merasa malu jika kedapatan pungli, dan adanya pengawasan dari atasan juga selalu diinfokan ke setiap pegawai setiap kali melakukan sosialiasi dampak yang akan didapat jika tetap melakukan tindakan pungli

Gambar 4. Integritas Pegawai

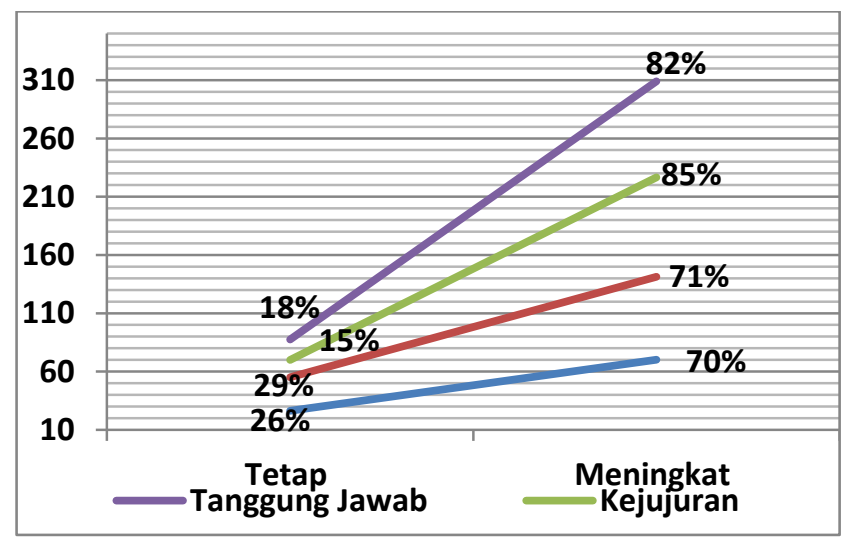

Catatan : Kemandirian, sebesar 4\% menjawab tidak tahu

(Data : 54 Responden petugas unit layanan)

Meningkatnya rasa takut terhadap perbuatan pungli oleh pegawai/petugas unit layanan ini berkorelasi dengan meningkatnya, kejujuran, kedisiplinan tangung jawab dan kemandirian pegawai di lingkungan Kemenkumham sejak tahun 2016- 2017.

\section{B. Penghambat UPP dalam pelaksanaan pemberantasan pungli di lingkungan Kemenkumham}

Dalam praktiknya pungli dapat dilakukan oleh mereka yang memiliki kewenangan atau kekuasaan atas kepentingan publik. Masyarakat ada dalam posisi membutuhkan dan merasa dirinya ada dalam posisi "memohon" yang harus tunduk pada syaratsyara tyang ditentukan oleh pemegang kewenangan tersebut. Maka langkah pemberantasan pungli sebagai bagian reformasi hukum bisa dibenarkan. Masyarakat harus mulai berani melaporkan praktik- praktik pungli. Masyarakat tidak perlu merasa dirinya sebagai objek yang dapat diperlakukan sewenang-wenang melalui praktik pungli karena, secara yuridis justru masyarakat berhak mendapatkan pelayanan yang baik dari negara sesuai denang peraturan hukum yang berlaku. Namun upaya pemerintah untuk memberantas pungli yang sangat masif itu bukan hal yang mudah dilaksanakan di lapangan. Pemberantasan korupsi adalah satu hal yang tidak mudah dilakukan. Di antara usaha yang sedang dilakukan tersebut adalah dengan adanya UPP Kemenkumham sebagai pengejawantahan dari niat luhur pemerintah untuk memberantas korupsi, terutama di lingkungan Kementerian Hukum dan HAM. dalam pelaksanaannya UPP terhambat beberapa faktor diantaranya:

\section{Faktor Penghambat Pada Fungsi Pencegahan}

Kegiatan pencegahan yang dilakukan oleh pokja pencegahan UPP Kanwil diantaranya adalah dengan melakukan sosialisasi tetapi, sosialisasi tersebut biasanya dilaksanakan bersamaan dengan kegiatan - kegiatan lain yang dilakukan oleh Kanwil karena UPP tidak memiliki anggaran sendiri, masih terbentur dengan kegiatan tugas pokok dan fungsi, kurangnya arahan yang berkelanjutan di tingkat pusat, lebih menekankan tindakan funishment dengan mengesampingkan reward, kemudian UPP Kanwil juga melakukan pencegahan pungli dengan melakukan sidak terutama di UPT, karena titik peluang terjadi pungli di daerah patut diduga lebih banyak terjadi pada UPT (Lapas, Rutan, Imigrasi) tetapi hal ini seringkali sudah diketahui oleh sebagian besar pegawai. 


\section{Faktor penghambat pada fungsi Penindakan}

Salah satu fungsi yang diemban oleh UPP Kemenkumham salah satunya adalah Penindakan, tetapi fungsi ini belum begitu banyak berperan, karena berdasarkan data rata-rata laporan yang masuk ke setiap UPP Kanwil dan UPT berjumlah 1- 2 laporan, karena pokja penindakan akan bekerja setelah ada laporan atau indikasi pungli yang dilakukan oleh pegawai. Laporan yang diterima biasanya melalui surat yang ditujukan kepada Kepala Satauan Kerja.

Dalam pelaksanaannya pokja penindakan belum memiliki format kerja yang baku, selama ini lebih banyak melakukan sosialisasi kepada pegawai dan pemantauan-pemantau. Batasbatas pekerjaan menurut responden sebaiknya sudah ada dituangkan dalam Standar Operasional Prosedur (SOP), karena SOP akan menjadi acuan dan arah bagi pegawai yang terlibat dalam tim UPP Kanwil dan Satgas Saber Pungli di UPT untuk dapat melaksanakan pekerjaanya dengan efektif sesuai pekerjaan masing-masing. Berdasarkan data $67 \%$ responden menyatakan bahwa sebagian besar UPP Kanwil dan UPT belum membuat/memiliki $\mathrm{SOP}^{16}$ terkait dengan pelaksanan peran UPP Kanwil dalam memberantas pungli di lingkungan Kemenkumham. Sementara yang menjawab "sudah" memiliki SOP sebesar 33 $\%$ menyatakan SOP tersebut dibuat sendiri oleh masing-masing unit kerja. Sementara untuk SOP yang berlaku resmi untuk setiap UPP Kemenkumham, pada saat tim pengambilan data lapangan ${ }^{17}$ belum tersedia.

\footnotetext{
${ }^{16}$ Moekijat. 2008. Adminitrasi Perkantoran. Bandung: Mandar Maju. Standar Opresional Prosedur atau yang lebih sering kita sebut dengan SOP adalah Standar Operasional Prosedur (SOP) adalah urutan langkah-langkah (atau pelaksanaanpelaksanaan pekerjaan), di mana pekerjaan tersebut dilakukan, berhubungan dengan apa yang dilakukan, bagaimana melakukannya, bilamana melakukannya, di mana melakukannya, dan siapa yang melakukannya.

Baca juga Hartatik, Indah Puji. 2014. Buku Praktis

Mengembangkan SDM. Jogjakarta. Laksana. hal. 30Tujuan di buatnya SOP Untuk menjelaskan alur tugas, wewenang dan tanggung jawab dari petugas yang terkait, juga untuk menilai mutu pelayanan.

${ }^{17}$ Lata lapangan diambil pada bulan Mei- Juni 2017
}

\section{Faktor Penghambat Pada Fungsi Yustisi}

Pada saat pengembilan data lapangan pada kajian ini, belum ditemukan tindakan kongret yang telah dilakukan oleh tim yustisi UPP Kanwil. Patut diduga hal ini karena belum ada pemahaman yang sama diantara anggota tim UPP. Dalam pengertiannya, arti Yustisi secara bahasa adalah segala sesuatu yang berkaitan dengan peradilan atau kehakiman. Di Indonesia, yustisi juga bermakna sebagai "penegakan hukum". ${ }^{18}$ jadi pengertian Yustisi adalah suatu upaya penegakan hukum yang dilakukan oleh penegak hukum dengan mengunakan sistem peradilan di tempat. Sedangkan pengertian non yustisi adalah upaya penegakan hukum melalui pendekatan yang sifatnya lebih ke preventif (pencegahan) terhadap segala sesuatu yang berpotensi atau mempunyai kecenderungan untuk menciptakan suatu pelanggaran hukum. ${ }^{19}$ Pemahaman yang sama tentu saja diperlukan agar tugas-tugas dapat terlaksana dengan baik. Agar tugas bisa berjalan baik dengan perlu ada panduan pelaksanaan tugas dan fungsi, dengan harapan agar fungsi yustisi dapat berfungsi secara profesional, dapat memberikan rekomendasi sesuai atauran yang berlaku.

\section{Faktor Penghambat pada Mekanisme Kerja}

Organisasi UPP dibentuk dengan tujuan untuk memberantas pungli yang ada di lingkungan Kemenkumham dengan cara mengoptimalkan pemanfaatan personil, satuan kerja, dan sarana prasarana di lingkungan Kemenkumham. Dalam mengoptimalkan tugas-tugas tersebut dalam pelaksanan kajian ini belum menemukan data yang terkait dengan mekanisme kerja UPP yang kongret dari pusat maupun kanwil dan UPT, dalam bentuk standar yang baku. Uraian tugas sampai saat ini belum diatur. Kepmen M.HH06.PW.02.03 Tahun 2016 tentang UPP di lingkungan Kemenkumham hanya memuat susunan keanggotan yang melibatkan setiap unit kerja di lingkungan Kemenkumham. Sementara mekanisme kerja tim ini belum diatur secara detail (apa siapa dan melakukan apa). Data yang kami peroleh menunjukan lebih seringnya setiap UPP Kanwil pada setiap pokja melaksanakan sosialisasi. Satgas

\footnotetext{
${ }^{18} \mathrm{http}: / /$ www.definisimenurutparaahli.com/pengertian -yustisi/ diakses Rabu, 26 -7-2017 ; pukul 14.28 Wib

${ }^{19} \mathrm{lbid}$
} 
Saber pungli yang dibentuk berdasarkan SK kepala satuan kerja beranggotakan pegawai di lingkungan UPT bertujuan untuk mengawasi kegiatan pegawai yang terindikasi melakukan tindakan pungli tapi. Pengawasan secara internal memang sudah dilakukan tapi, itu kurang efektif karena sifatnya masih dalam satuan internal organisasi dalam pelaksanaannya akan berbenturan dengan teman rekan kerja lain.

\section{Faktor Penghambat Pada Personil}

Personil atau anggota tim UPP, dengan memanfaatkan personil satuan kerja, sarana dan prasarana di lingkungan Kemenkumham. Hal ini tentu saja berdampak pada kinerja dari Tim itu sendiri, secara organisasi UPP Kemenkumham Pusat berangotakan para pejabat esslon I, II dan III yang secara struktur sudah memiliki tugas dan fungsi yang menuntut untuk diselesaikan. Hal ini berimbas pada tugas sebagai anggota tim UPP sering terlewatkan/terabaikan, karena anggota tim UPP beranggotakan para pejabat yang mempunyai tugas pokok tersendiri sesuai dengan jabatan masing-masing yang tersebar di setiap unit kerja. Hal ini juga menyebabkan anggota Tim UPP cq pokja-pokja kesulitan dalam berkoordinasi untuk melakukan langkah Pencegahan, Penindakan dan Yustisi tindakan pungli di lingkungan Kemenkumham. Berdasarkan data yang tersedia dapat dikatakan bahwa tim UPP akan bekerja jika ada berita yang sudah tersebar di masyarakat untuk menindaklajuti berita tersebut. Namun hasil akhir dari tindak lanjut tersebut banyak yang tidak di ketahui atau tidak dipublikasikan.

Berdasarkan data yang diperoleh, diantara para angota tim UPP maupun Satgas Saber Pungli yang ada di UPT, terkadang ada rasa takut dan juga tidak enak dari jajaran UPT untuk melaporkan dugan pungli yang ada di Unit kerjanya masing-masing. Personil tim UPP di daerah terdiri dari para kepala Divisi yang dibentuk dengan Surat keputusan kepala Kantor Wilayah Kemenkumham, sebenarnya adalah turunan dari tim UPP Pusat secara garis komando. Dari hasil wawancara, dalam pelaksanaan tugasnya Tim UPP Kanwil seringkali terbentur dengan tupoksi masingmasing divisi. Dari sisi personality pegawai yang terlibat dalam tim UPP maupun satgas saber pungli UPT masih kurang pemahamannya tentang tugas pemberantasan pungli.

\section{Faktor Penghambat pada Program}

Dalam sebuah organiasi, walaupun itu dibentuk hanya untuk tujuan tertentu, akan tetapi program atau kegiatan yang akan dilaksanakan seyogyanya sudah terprogram dengan baik, kegiatannya, tujuan dan hasil akhir yang ingin dicapai. Berdasarkan data yang kami diperoleh dari beberapa UPP yang ditemui rata-rata belum memiliki program kerja yang terukur dan target hasil yang ingin di capai baik kualitas maupun kuantitas. Kualitas UPP dalam pemberantasan Pungli di Lingkungan Kanwil pada akhirnya akan ditentukan oleh kualitas dan kuantitas personil yang ada di dalamnya, di samping dukungan dana dan prasaranya.

\section{Faktor Penghambat pada Pem- biayaan/Anggaran}

UPP seperti dijelaskan di atas adalah salah satu unit kerja yang di bentuk secara Ad hoc, khusus untuk menangulagi pungli yang ada di lingkungan Kemenkumham. Dalam pelaksanaanya unit ini belum didukung dengan anggaran yang dikhususkan untuk kegiatan tim UPP dalam perannya menangulagi pungli di lingkungan Kemenkumham. Tentu saja hal ini sangat dilematis karena harapan yang sangat besar terhadap tim ini dapat bekerja secara maksimal. Organiasi yang baik adalah organiasi yang memiliki anggaran untuk melaksanakan kegiatan, sebaik apapun oranisasi tersebut bila tidak didukung dengan ketersediaan dana mustahil dapat berjalan. Anggaran sebagai salah satu alat bantu manajemen dalam pelaksanaan peranan, karena dengan anggaran manajemen dapat merencanakan, mengatur dan mengevaluasi jalannya suatu kegiatan. Menurut M. Nafarin mengemukakan bahwa: "Anggaran adalah rencana tertulis mengenai kegiatan suatu organisasi yang dinyatakan secara kuantitatif untuk jangka waktu tertentu dan umumnya dinyatakan dalam satuan uang. ${ }^{20 "}$ Karena ketiadaan anggaran tersebut kegiatan yang dilakukan oleh tim UPP Kanwil diantaranya pelaksanaan sosialiasi yang harus dilakukan bersamaan dengan kegiatan lainnya yang telah dianggarkan pada anggaran Kanwil.

\section{Faktor Penghambat pada kesadaran Masyarakat}

Mengharapkan kesadaran dari masyarakat bukanlah perkara gampang, apalagi untuk

\footnotetext{
${ }^{20}$ M Nafarin, 2012, "Penganggaran Perusahaan", Salemba empat, Jakarta. Hal 19
} 
urusan pungli. Pada sisi lain, masyarakat pun kerap menyumbang kontribusi terhadap tumbuh suburnya praktek pungutan liar dengan cara membiasakan memberi uang tanpa mampu bersikap kritis melakukan penolakan pembayaran di luar dari biaya resmi. Prilaku 'memberi' masyarakat untuk memperlancar urusan dengan birokrat susah untuk dihilangkan karena telah berlangsung selama berabadabad. Mengurai terjadinya pungli bukan hanya karena kurangnya kesadaran dari masyarakat. Melainkan ada faktor lain yang mempengaruhi diantaranya adanya sifat tamak manusia, moral yang kurang kuat, penghasilan yang tidak mencukupi, kebutuhan hidup yang mendesak, gaya hidup yang konsumtif, malas atau tidak mau kerja, ajaran agama yang kurang diterapkan, kebiasaan masyarakat yang suka memberi suap, kurangnya pemahaman masyarakat terhadap pungli dan kurangnya pengawasan ${ }^{21}$. Masyarakat patut diduga sebenarnya sudah mengetahui pungli yang ada di institusi Kemenkumham tetapi berdasarkan data yang diperoleh ada sebagian masyarakat yang diuntungkan dengan adanya pegawai yang masih bisa disuap dan jika mau melapor, ada ketakutan bila nanti berurusan lagi akan di persulit serta, takut bila laporan tersebut ditindaklajuti akan merepotkan pelapor nantinya pada proses hukum yang panjang. Pungli seperti halnya korupsi telah menjadi prilaku yang sulit diberantas hanya mengandalkan peraturan dan sanksi hukum yang berat. Lebih dari itu, sikap mental, prilaku korup dan paradigma birokrasi kita yang harus diubah ${ }^{22}$. Terjadinya tindakan pungli sebenarnya juga melibatkan pihak lain (masyarakat) sebagai korban. Dengan demikian edukasi pada masyarakat untuk tidak gampang mencari jalan pintas pelayanan birokrasi juga menjadi hal yang tidak kalah pentingnya. Masyarakat secara luas perlu mendapatkan informasi yang jelas dan lengkap seputar hak dan kewajibannya dalam proses pelayanan publik. Pembenahan pada sektor internal yang tidak berhenti pada penegakan sanksi dan aturan, juga pembenahan mental dan prilaku birokrasi sebagai sistem, serta sosialisasi yang berkesinambungan dan berkelanjutan pada masyarakat, dengan harapan praktik pungli

\footnotetext{
21 Sudikno Mertokusumo :

http://sudiknoartikel.blogspot.co.id/2008/03/meningk atkan-kesadaran-hukum-masyarakat.html diakses 26 juli 2017. Pukul 14. 30 Wib

${ }^{22}$ Anhar Ada Widodo : Harian joglo Semar 18 juni 2010. Menghilangkan budaya pungli http://anhar.dosen.isi-ska.ac.id/archives/58 diakses
} 14 Agustus 2017 dapat diminimalisir, alih-alih dihapuskan. Media sebagai alat kontrol sosial yang masih dianggap efektif diharapkan dapat mampu lebih berperan dalam menangulangi pungli.

\section{Peran UPP Dalam Mewujudkan Akuntabilitas dan Integritas Aparatur Dalam Pelaksanaan Tugas Dan Fungsi.}

Peranan UUP Kemenkumham adalah melaksanakan pemberantasan pungutan liar secara efektif dan efesien dengan mengoptimalkan pemanfaatan personil. ${ }^{23}$ Dalam pelaksanaan peran tersebut terdapat harapan-harapan masyarakat akan terciptanya pelayaan yang baik teransparan dan tentu saja tanpa pungli. Dalam pandangan David Berry, peranan dapat dilihat sebagai bagian dari struktur masyarakat sehingga struktur masyarakat dapat dilihat sebagai pola-pola peranan yang saling berhubungan. ${ }^{24}$

\section{Gambar 5. Tanggapan Responden Penguna Unit Layanan terhadap Petugas Unit Layanan}

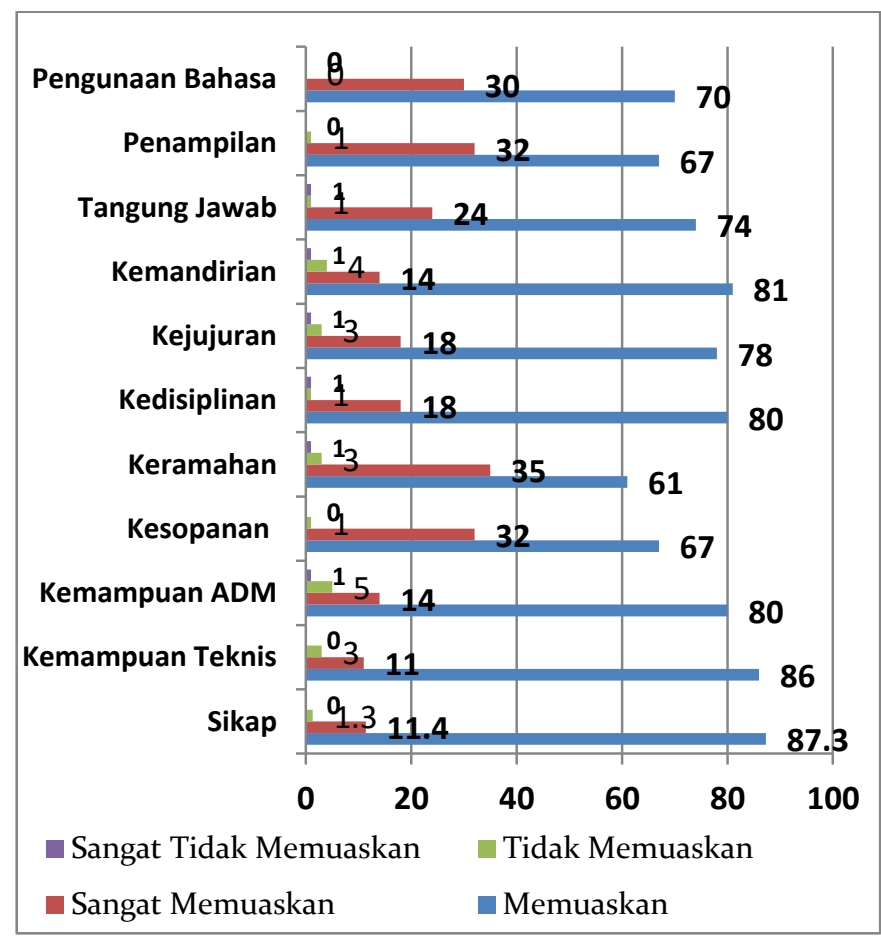

23 Keputusan Menteri Hukum dan HAM Nomor M.HH.06.PW.02.03 Tahun 2016 tentang Unit Pemberantasan Pungli di Lingkungan Kementerian Hukum dan HAM.

${ }^{24}$ Eka Dimas Puspita. http://mynewblogekadp.blogspot.co.id/2017/04/peng ertian-dan-jenis-jenis-teori-adm.html 
(Data berdasarkan : 79 Responden penguna Unit layanan, terdiri dari WBP, Pengunjung WBP dan Pemohon Paspor)

Dari data di atas menunjukan bahwa penilaian masyarakat penguna layanan terhadap unit layanan yang ada di lingkungan Kemenkumham menunjukan rata-rata masyarakat penguna layanan di lingkungan Kemenkumham sudah puas atas pelayanan yang diberikan. Masyarakat menilai pelayanan di Kemenkumham sudah banyak yang dilakukan secara elektronik sehingga intensitas pertemuan antara pemohon dengan petugas dapat diminimalisir. Menurut responden pelayanan secara elektronik dapat meminimalisir terjadinya pungli baik dari pegawai ke masyarakat, maupun dari masyarakat ke pegawai. Misalkan ada beberapa lapas yang sudah menerapkan layanan kunjungan secara elektronik, ada juga Kantor Imigrasi yang menerapkan layanan pengambilan nomor antrian secara elektronik dan ada juga yang menerapan pembatasan layanan permohonan paspor. Kesemua jenis inovasi layanan tersebut merupakan salah satu upaya yang dilakukan untuk menangulagi pungli oleh Kepala Unit Layanan di lingkungan Kemenkumham.

Untuk menganalisa peran UPP dalam mendorong Akuntabilitas dan Integritas pegawai, pada kajian melakukan survey terhadap 54 Petugas Unit layanan. Yang selama ini merasakan langsung dampak dari terbentuknya UUP Kemenkumham. Adapun hipotesa yang akan diuji adalah :

Tabel. 1.Peran UPP dengan Kedisiplinan

\begin{tabular}{ccc|c} 
& \multicolumn{2}{c}{ Correlations } \\
& & $\begin{array}{c}\text { PERAN } \\
\text { UPP }\end{array}$ & KEDISIP \\
& & LINAN \\
\hline PERAN & $\begin{array}{c}\text { Pearson } \\
\text { UPP }\end{array}$ & 1 & $.639^{* *}$ \\
& Correlation & & \\
\cline { 2 - 4 } & Sig. (2-tailed) & & .000 \\
\cline { 2 - 4 } & $\mathrm{N}$ & 53 & 53 \\
\hline KEDIPLIN & $\begin{array}{c}\text { Pearson } \\
\text { AN }\end{array}$ & $.639^{* *}$ & 1 \\
\cline { 2 - 4 } & Correlation & & \\
\cline { 2 - 4 } & Sig. (2-tailed) & .000 & \\
\hline
\end{tabular}

**. Correlation is significant at the 0.01 level (2tailed).

Dari tabel di atas diperoleh korelasi person 0,639 artinya terdapat hubungan yang signifikan antara peran UPP Kemenkumham dengan kedisiplinan Pegawai di lingkungan Kemenkumham. Tingkat hubungan korelasi antara peran UPP Kemenkumham dengan kedisiplinan terindentifikasi kuat, hal ini yang ditunjukan dengan nilai korelasi mendekati +1 dengan $\mathrm{P}$ - value/sing sama dengan $0.00<0,05$ dapat disimpulkan terdapat hubungan yang signifikan antara kedua variabel.

Tabel.2. Peran UPP dengan Kejujuran Correlations

\begin{tabular}{|c|c|c|c|}
\hline & & $\begin{array}{l}\text { PERAN } \\
\text { UPP }\end{array}$ & $\begin{array}{l}\text { KEJUJU } \\
\text { RAN }\end{array}$ \\
\hline \multirow[t]{3}{*}{$\begin{array}{l}\text { PERAN } \\
\text { UPP }\end{array}$} & $\begin{array}{l}\text { Pearson } \\
\text { Correlation }\end{array}$ & 1 & $.781^{* \star}$ \\
\hline & Sig. (2-tailed) & & .000 \\
\hline & $\mathrm{N}$ & 53 & 53 \\
\hline \multirow[t]{3}{*}{$\begin{array}{l}\text { KEJUJU } \\
\text { RAN }\end{array}$} & $\begin{array}{l}\text { Pearson } \\
\text { Correlation }\end{array}$ & $.781^{* *}$ & 1 \\
\hline & Sig. (2-tailed) & .000 & \\
\hline & $\mathrm{N}$ & 53 & 54 \\
\hline
\end{tabular}

${ }^{* *}$. Correlation is significant at the 0.01 level (2tailed).

Korelasi hubungan antara peran UPP dengan kejujuran pegawai pada tabel. 2 menunjukan 0,781 artinya terdapat hubungan yang signifikan antara kedua variabel tersebut. jadi peran UPP mendorong kejujuran pegawai dalam pelaksanan tugas pokok dan fungsi.

Tabel. 3. Peran UPP dengan Kemandirian Correlations

\begin{tabular}{llr|r} 
& & $\begin{array}{c}\text { PERANU } \\
\text { PP }\end{array}$ & \multicolumn{1}{c}{ MANDI } \\
& & RI \\
\hline PERANU & Pearson & 1 & $.908^{* *}$ \\
& Correlation & & \\
\cline { 2 - 4 } & Sig. (2-tailed) & & .000 \\
\cline { 2 - 4 } MANDIRI & $\mathrm{N}$ & 53 & 53 \\
\hline & Pearson & $.908^{* *}$ & 1 \\
& Correlation & & \\
\cline { 2 - 4 } & Sig. (2-tailed) & .000 & \\
\cline { 2 - 4 } & $\mathrm{N}$ & 53 & 54 \\
\hline
\end{tabular}

${ }^{* *}$. Correlation is significant at the 0.01 level (2tailed).

Kemandirian adalah salah satu komponen penilaian integritas pegawai, nilai korealasi hubungan antara Peran UPP Kemenkumham dengan Kemandirian Pegawai menunjukan nilai hitung pada SPSS sebesar 0,908 dengan sig $0,00<0,05$ yang artinya terdapat hubungan yang signifikan sangat kuat. Hal ini berarti bahwa pada tabel 3. Menunjukan peran UPP mempengaruhui secara positif terhadap kemandirian pegawai dalam pelaksanaan tugas pokok dan fungsi. 
Tabel. 4 Peran UPP dengan Tangung Jawab Keuangan

Correlations

\begin{tabular}{|c|c|c|c|}
\hline & & $\begin{array}{c}\text { PERANU } \\
\text { PP }\end{array}$ & $\begin{array}{c}\text { TJWBKE } \\
U\end{array}$ \\
\hline \multirow[t]{3}{*}{$\begin{array}{l}\text { PERANU } \\
\text { PP }\end{array}$} & $\begin{array}{l}\text { Pearson } \\
\text { Correlation }\end{array}$ & 1 & $.920^{* x}$ \\
\hline & Sig. (2-tailed) & & .000 \\
\hline & $\mathrm{N}$ & 53 & 51 \\
\hline \multirow[t]{3}{*}{$\begin{array}{l}\text { TJWBKE } \\
U\end{array}$} & $\begin{array}{l}\text { Pearson } \\
\text { Correlation }\end{array}$ & $.920^{* *}$ & 1 \\
\hline & Sig. (2-tailed) & .000 & \\
\hline & $\mathrm{N}$ & 51 & 52 \\
\hline
\end{tabular}

**. Correlation is significant at the 0.01 level (2tailed).

Pada tabel 4. Menunjukan bahwa nilai akuntabilitas Keuangan Pegawai terkorelasi sangat kuat $(0,920)$ terhadap peran UPP Kemenkumham. Ini berarti dengan terbentuknya UPP dan peran UPP Kemenkumham diantaranya Pencegahan, Penindakan dan Yustisi berdampak sangat signifikan terhadap pertangungjawaban keuangan pegawai di lingkungan Kemenkumham.

\section{Tabel. 5. Peran UPP dengan Tangung Jawab Administrasi Correlations}

\begin{tabular}{|c|c|c|c|}
\hline & & $\begin{array}{c}\text { PERANU } \\
\text { PP }\end{array}$ & $\begin{array}{c}\text { TJWBA } \\
\text { DM }\end{array}$ \\
\hline \multirow[t]{3}{*}{$\begin{array}{l}\text { PERANU } \\
\text { PP }\end{array}$} & $\begin{array}{l}\text { Pearson } \\
\text { Correlation }\end{array}$ & 1 & $.909^{* x}$ \\
\hline & Sig. (2-tailed) & & .000 \\
\hline & $\mathrm{N}$ & 53 & 52 \\
\hline \multirow[t]{3}{*}{$\begin{array}{l}\text { TJWBAD } \\
\text { M }\end{array}$} & $\begin{array}{l}\text { Pearson } \\
\text { Correlation }\end{array}$ & $.909^{* *}$ & 1 \\
\hline & Sig. (2-tailed) & .000 & \\
\hline & $\mathrm{N}$ & 52 & 53 \\
\hline
\end{tabular}

${ }^{* *}$. Correlation is significant at the 0.01 level (2tailed).

Tabel. 5, menunjukan bahwa antara peran UPP dengan tangung jawab administrasi pegawai di lingkungan Kemenkumham dalam pelaksanaan tugas pokok dan fungsi terkorelasi sangat kuat (0.909). dalam artian peran UPP Kemenkumham yang dibentuk untuk menangulagi pungli di lingkungan Kemenkumham berdampak juga terhadap akuntabilitas administasi pegawai

Hasil SPSS keseluruhan menunjukan bahwa Peran UPP Kemenkumham (Pencegahan, Penindakan dan Yustisi) memiliki rata korelasi positif dapat mendorong integritas dan akuntabilitas pegawai dalam pelaksanaan tugas pokok dan fungsi pegawai di lingkungan Kemenkuham.

\section{PENUTUP}

\section{Kesimpulan}

Peran UPP Kemenkumham, dalam pelaksanan fungsi pencegahan, penindakan dan yustisi di lingkungan Kemenkumham, sudah berjalan pada setiap Kanwil dan UPT, walaupun belum maksimal. Tangapan responden terhadap hal ini menunjukan bahwa dari sisi komposisi keanggotaan 93\% responden menilai sudah tepat. Efektivitas menangulangi pungli $86 \%$ responden menilai sudah efektif. Timbulnya rasa takut dari pegawai sebesar $88 \%$. mengindikasikan bahwa program pemberantasan pungli di lingkungan Kemenkumham sudah berjalan. Peningkatan integritas dan akuntabilitas di kalangakan pegawai yang kami survei, menunjukan peningkatan rata-rata pada kisaran $60 \%$.

Ada beberapa faktor penghambat dalam pelaksanaan peran UPP dalam pemberantasan pungli di lingkungan Kemenkumham diantaranya: belum tersedianya anggaran khusus untuk UPP, belum ada pedoman mekanisme kerja yang menjadi standar bersama dalam pelaksanaan peran UPP. Uraian tugas setiap anggota sampai saat ini belum diatur, Kepmen M.HH-06.PW.02.03 Tahun 2016 tentang UPP di lingkungan Kemenkumham hanya memuat susunan keanggotan yang melibatkan setiap unit kerja di lingkungan Kemenkumham. Sementara mekanisme kerja dari setiap pokja belum diatur secara detail. Masih ada personil UPP yang masih kurang pemahamannya tentang pemberantasan pungli. Target kerja yang belum terukur dan program kerja yang belum kongret serta kebiasaan masyarakat yang suka memberi suap, patut diduga karena kurangnya pemahaman masyarakat terhadap pungli.

Berdasarkan perhitungan dengan mengunakan SPSS version 24, menunjukan tingkat korelasional peran UPP Kemenkumham dengan Akuntabilitas dan Integritas Pegawai terlihat rata-rata di atas 0,05 atau interval korelasi 0,639 - 909. Hal ini menunjukan tingkat hubungan 'kuat' sampai dengan "sangat kuat" antara peran UPP Kemenkumham dengan akuntabilitas dan integritas pegawai. Walaupun peran UPP belum maksimal dalam pelaksanaanya tapi jelas bahwa keberadaan UPP Kemenkumham telah menstimulus akuntabilitas dan integritas pegawai dalam pelaksanaan tugas pokok dan 
fungsi. Gambaran keseluruhan berdasarkan data yang terkumpul pada kajian ini menunjukan bahwa, akuntabilitas dan Integritas pegawai dalam pelaksanan tugas dan fungsi pelayanan di lingkungan Kemenkumham dapat didorong dengan memaksimalkan pelaksanaan peran pencegahan, peran penegakan dan peran yustisi pada UPP Kemenkumham.

\section{Rekomendasi}

1. Untuk lebih meningkatkan peran UPP Kemenkumham dalam pelaksanaan pemberantasanan pungli di lingkungan Kemenkumham perlu adanya.

a) Penguatan pada tugas pencegahan dengan cara memasang pamphlet di titik pelayanan, himbauan untuk tidak melakukan tindakan pungli, beserta akibat hukum bagi yang melanggar baik pegawai maupun masyarakat. Melakukan sosialiasi ke sekolah-sekolah yang ditujukan ke siswa, dan sosialiasi pungli ke para istri pegawai. Hal ini berguna untuk pencegahan sedini mungkin tindakan pungli.

b) Penguatan tugas penindakan dengan menambahkan fungsi intelegen. Hal ini bertujuan untuk tetap menimbulkan rasa takut pegawai terhadap tindakan pungli dan sebagai sarana pengawasan.

c) Penguatan pada tugas yustisi, dengan cara meningkatkan kemampuan/pemahaman anggota pokja yustisi tentang hukum dan kepegawaian. Hal ini berguna agar tidak keliru dalam memutuskan tindakan hukum bagi pegawai/petugas yang melanggar.

d) Dalam memberikan rekomendasi hukuman kepada pegawai yang terbukti bersalah, tanpa memandang pangkat, jabatan dan kedudukan.

e) Membuat standar operasional prosedur (SOP) yang berlaku Nasional, terkait dengan peran tugas dan fungsi UPP di lingkungan Kemenkumham;

f) Membuat uraian tugas pada setiap anggota tim UPP Kanwil dan satgas Saber Pungli UPT;

g) Uraian kerja tersebut dibuat pada setiap kelompok kerja sesuai dengan susunan keanggotaan UPP.

h) Perlu dilakukan evaluasi susunan keangotaan UPP Kemenkumham. i) Memberikan reward kepada satuan kerja yang berhasil menangulagi pungli; menyusun mekanisme pemberian reward tersebut dan reward yang akan diberikan seperti apa.

j) Membangun kerjasama dengan Pemerintah Daerah (PEMDA) dalam penangulangan pungli.

k) Membuat sistem pemantauan secara elektronik, yang bertujuan agar Tim Pemantau Pungli Kemenkumham dapat memantau kegiatan yang dilaksakan oleh tiap-tiap UPP Kanwil dan UPT, yang dilaporkan secara priodik.

I) Meningkatkan kemampuan dan keterampilan anggota UPP Kemenkumam, dengan melakukan pelatihan bersama penanganan kejahatan pungli.

2. Untuk meminimalisir hambatan-hambatan dalam pelaksanaan pemberantasan pungli di lingkungan Kemenkuham diantaranya:

a) Menyedikan anggaran khusus untuk kegiatan UPP baik yang di pusat maupun UPP di Kanwil dan UPT.

b) Membangun atau mendirikan sistem komunikasi bersama untuk memudahkan koordinasi.

c) Perlu adanya sekretariat bersama UPP Kemenkumham, hal ini berguna untuk memudahkan berkoordinasi dan memudahkan menerima laporan pengaduan masyarakat.

d) Setiap UPP pusat maupun daerah menyediakan layanan pengaduan atau penyampaian informasi, yang berguna untuk memudahkan komunikasi dengan masyarakat serta memudahkan masyarakat dalam mengawasi kinerja pegawai.

3. Hal apapun yang berkaitan dengan pungutan yang tidak resmi harus bersama kita dihilangkan. Dengan keterpaduan itulah diharapkan pelaksanaan pemberantasan pungli di lingkungan Kemenkumham ini akan efektif. Semangat pemberantasan pungli bukanlah terletak pada jumlah kerugian yang ditimbulkannya, namun lebih pada prilaku pungli yang hendak dihilangkan.

4. Pungli tidak hanya berdampak pada buruknya kualitas pelayanan publik. Bila hal tersebut dibiarkan, pada akhirnya akan 
Peran Unit Pemberantasan Pungutan..........(Nizar)

menjalar ke hal yang lebih luas lagi. Pungli juga melemahkan daya saing nasional, dan yang perlu diingat, "Penindakan dalam penanganan pungli agar berpedoman pada ketentuan perundang-undangan yang berlaku". 


\section{DAFTAR PUSTAKA}

\section{Buku}

Adam I. Indrawijaya. 2000. Perilaku organiasi. Jakarta Sinar baru Algesindo.

Soedjono, Dirdjosisworo. 1983. Pungli: Analisa Hukum \& Kriminologi, cetakan ke-2. Bandung: Sinar Baru.

Soedjono, Soedjono, Dirdjosisworo. 1983. Pungli: Analisa Hukum \& Kriminologi, cetakan ke-2. Bandung: Sinar Baru.

Moekijat. 2008. Adminitrasi Perkantoran. Bandung: Mandar Maju

Hartatik, Indah Puji. 2014. Buku Praktis Mengembangkan SDM. Jogjakarta. Laksana.

\section{Hasil Penelitian/Tesis, Skripsi/ Majalah}
BPKP. Upaya Pencegahan dan Penanggulangan Korupsi pada Pengelolaan Pelayanan Masyarakat. Jakarta: Tim Pengkajian SPKN RI. 2002

I Wayan Sudana: Mewujudkan Birokrasi yang Mengedepankan Etika Pelayanan Publik : 2006

\section{Internet}

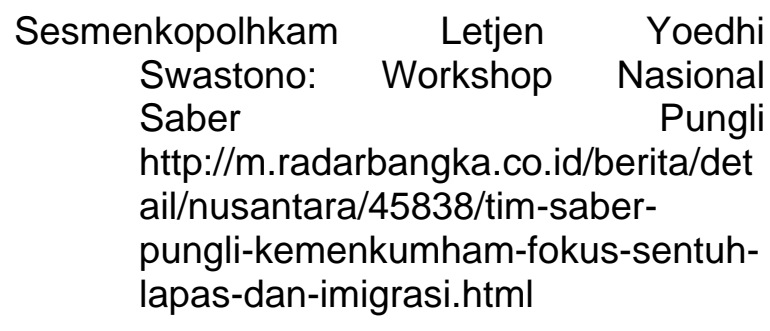

Fuska Sani Evani/PCN: http://www.beritasatu.com/hukum/39 8101-petugas-imigrasi-yogyaterkena-ott-satgas-pungli.html diakses 27 Maret 2017.

https://ilmupemerintahan.wordpress.com/20 09/06/06/mewujudkan-birokrasiyang-mengedepankan-etikapelayanan-publik/

Ardeno Kurniawan, S.E., M.Acc, Ak.: Fraud di Sektor Publik dan Integritas Nasionalhttp://www.bpkp.go.id/public /upload/unit/sulsel/files/paraikatte/26 _paraikatte_edisi_26_1_web.pdf diakses 1 Maret 2017
Dewi ;

http://www.kajianpustaka.com/2016/10/pung utan-liar-pungli.html diakses 19 juli 2017. Pukul 14.20 wib

Eka Dimas Puspita.

http://mynewblogekadp.blogspot.co.id/2017/ 04/pengertian-dan-jenis-jenis-teoriadm.html

Sudikno Mertokusumo: meningkatkan kesadaran Hukum Masyarakat. http://sudiknoartikel.blogspot.co.id/2 008/03/meningkatkan-kesadaranhukum-masyarakat.html diakses

http://www.definisimenurutparaahli.com/pen gertian-yustisi/

http://sudiknoartikel.blogspot.co.id/2008/03/ meningkatkan-kesadaran-hukummasyarakat.html diakses 26 juli 2017.

http://e-designonline.blogspot.co.id /2014/06/tingkat-kesadaranmasyarakat-dan.html

\section{Peraturan Perundang- Undangan}

Republik Indonesia, Kitap Undang-undang Hukum Pidana, KUHP Nomor 1 tahun 1947

Republik Indonesia, Undang-Undang Tentang Perubahan Atas UndangUndang Nomor 31 Tahun 1999 Tentang Pemberantasan Tindak Pidana Korupsi. UU Nomor 20 Tahun 2001

Republik Indonesia, Peraturan Presiden Tentang Satuan Tugas Sapu Bersih Pungutan Liar. Perpres Nomor 87 Tahun 2016

Republik Indonesia, Keputusan Menteri Hukum dan HAM RI, tentang Tim Pemantau Pemberantasan Pungutan Liar di Lingkungan Kementerian Hukum dan HAM. Kepmen Nomor M.HH-04.PW.02.03 Tahun 2016

Republik Indonesia, Keputusan Menteri Hukum dan HAM tentang Unit Pemberantasan Pungli di Lingkungan Kementerian Hukum dan HAM. Kepmen Nomor M.HH.06.PW.02.03 Tahun 2016 